\title{
Benzo(a)pyrene-induced a mitochondria-independent apoptosis of liver in juvenile Chinese rare minnows (Gobiocypris rarus) ${ }^{2 / 2}$
}

\author{
Jinmiao Zha a, b, *, Xiangsheng Hong a, b, e , Haiou Rao ${ }^{\text {a, b }}$, Lilai Yuan ${ }^{\text {a, b }}$, Zijian Wang a, c \\ Satyanarayanan Senthil Kumaran ${ }^{\mathrm{d}}$ \\ ${ }^{a}$ Key Laboratory of Drinking Water Science and Technology, Research Center for Eco-Environmental Sciences, Chinese Academy of Sciences, Beijing 100085, \\ China \\ ${ }^{\mathrm{b}}$ Beijing Key Laboratory of Industrial Wastewater Treatment and Reuse, Research Center for Eco-Environmental Sciences, Chinese Academy of Sciences, \\ Beijing 100085, China \\ ${ }^{\mathrm{c}}$ State Key Laboratory of Environmental Aquatic Chemistry, Research Center for Eco-Environmental Sciences, Chinese Academy of Sciences, Beijing 100085, \\ China \\ d Unit of Toxicology, Bharathiar University, Coimbatore 641 046, India \\ e University of Chinese Academy of Sciences, Beijing 100085, China
}

\section{A R T I C L E I N F O}

\section{Article history:}

Received 15 April 2017

Received in revised form 28 July 2017

Accepted 1 August 2017

Available online 8 August 2017

\section{Keywords:}

Benzo(a)pyrene

Chinese rare minnow (Gobiocypris rarus)

Histopathology

Apoptosis

Mitochondrial pathway

\begin{abstract}
A B S T R A C T
To examine the effects of BaP on tissue apoptosis, laboratory studies were conducted using juvenile Chinese rare minnows (Gobiocypris rarus) exposed to 1, 5, 20, and $80 \mu \mathrm{g} / \mathrm{L}$ of BaP for 28 days. The posttreatment pathological findings in the liver were associated with hepatocyte swelling, karyopyknosis, and karyorrhexis. Moreover, an increase in the goblet cells in the intestine, epithelial hyperplasia of the gills and fusion of gill lamellae were observed. Significant increases in hepatocyte apoptosis using the TUNEL stain were observed in the liver tissue but not in the intestine and gills. In addition, BaP exposure significantly up-regulated the mRNA levels of cyp1a1, p53, bax, bcl-2, and caspase-9 in the liver following the 5,20 , and $80 \mu \mathrm{g} / \mathrm{L}$ treatments, whereas the apaf-1 was significantly down-regulated following all treatments. Moreover, the activities of caspase 3 and caspase 8 were markedly elevated, whereas the protein expression levels of Apaf- 1 were down-regulated following the 20 and $80 \mu \mathrm{g} / \mathrm{L}$ treatments. Taken together, our results suggested that BaP strongly induces tissue-specific apoptosis in vivo, leading to significant pathological changes. The responsiveness of apoptotic-related genes demonstrates that BaP induced apoptosis in the liver may be through a mitochondria-independent pathway.
\end{abstract}

๑) 2017 Published by Elsevier Ltd.

\section{Introduction}

Apoptosis occurs normally during different development stages and as a homeostatic mechanism to maintain cell populations in tissues (Marino et al., 2014). The mechanisms of apoptosis are very complex and are mainly categorized into intrinsic and extrinsic pathways (Verbrugge et al., 2010). The intrinsic (mitochondrial)

Abbreviations: BaP, benzo(a)pyrene; PAHs, polycyclic aromatic hydrocarbons; TUNEL, terminal deoxynucleotidyl transferase dUTP nick end labeling; apaf, apoptotic protease activity factor-1; AHR, aryl hydrocarbon receptor.

\& This paper has been recommended for acceptance by Dr. Harmon Sarah Michele.

* Corresponding author. Key Laboratory of Drinking Water Science and Technology, Research Center for Eco-Environmental Sciences, Chinese Academy of Sciences, 18 Shuangqing Road, Haidian District, Beijing, 100085, China.

E-mail address: jmzha@rcees.ac.cn (J. Zha). pathway involves $b c l-2$ pro-apoptotic proteins such as bax. This promotes the release of Cytochrome $c$, which is associated with the apoptotic protease activity factor-1 (apaf1) to form the apoptosome in the cytosol (Wu and Bratton, 2013). The apoptosome recruits Caspase-9, leading to its activation. Then, Caspase- 3 initiates the caspase cascade and is cleaved by activated Caspase- 9 (Chakraborty et al., 2012). Apoptosis also occurs as a defense mechanism, such as in immune reactions or when cells are damaged by disease or noxious agents (Aachoui et al., 2013; de Oliveira, 2016). Previously, inductions of apoptosis by PAHs and its metabolites in vitro had been reported (Chung et al., 2007; Souza et al., 2016).

Apoptosis was induced in the human lymphoblastic T-cell line LMAT exposed to TCDD, and caspase-3 activation via the Jun N-terminal kinase (JNK) was observed (Kikuchi et al., 2001). Furthermore, Kobayashi et al. (2009) reported that $\mathrm{Ca}^{2+} / \mathrm{CaM}$ signals might play an important role in the induction of apoptosis. In addition, 
PAH and its metabolites caused a rapid accumulation of the p53 gene product in human and mouse cells (Hirano et al., 2013; Huang et al., 2012). However, the pathways by which p53 leads to apoptosis are not well characterized, especially in fish.

Benzo(a)pyrene (BaP), a typical and extensively studied PAH, is widespread in our environment (Kim et al., 2013). The concentration of BaP in surface waters ranges from undetectable levels to $2.5 \mathrm{ng} \mathrm{L}^{-1}$ in the Henan Reach of the Yellow River (Sun et al., 2009). After a large-scale oil spill, nearly $20 \mu \mathrm{g} \mathrm{mL}^{-1}(79.37 \mu \mathrm{M})$ of BaP was detected in the near shore sea water environment of Mumbai (Ladwani et al., 2013). Importantly, carcinogenic and mutagenic effects of BaP in humans, animals and mammalian cell systems have been reported. In a previous study, serious pathological lesions were observed in liver sections of Fundulus heteroclitus after more than 8 months exposure to BaP (Wang et al., 2010; Wills et al., 2010). However, BaP itself is not genotoxic, its biotransformation by xenobiotic-metabolizing enzymes, including cyp1a1 and cyp1b1, transforms it into a toxic form (Huang et al., 2015; Yuan et al., 2013). These enzymes can be mediated by binding the aryl hydrocarbon receptor (AHR) with its metabolic intermediates, which bind covalently to DNA and thus result in DNA damage (Huc et al., 2006; Souza et al., 2016). Moreover, in the HepG2 cell assay, BaP metabolites triggered the initiation of the expression of functional genes, including cytochrome $p 450, m d m 2$, and $p 53$ along with metabolic activation within the cells (Van Delft et al., 2012). Recently, significantly higher amounts of BaP metabolites were formed from the BaP-pretreated Trp53(-/-) mice (Krais et al., 2016). Therefore, this new role for $\mathrm{p} 53$ in the metabolism of $\mathrm{BaP}$ found in vivo is very different from previous findings regarding its role in an in vitro setting (Hockley et al., 2008; Wohak et al., 2016).

Since there are obvious geographical features in the biological groups of water ecosystems in different regions, it is impossible to assess the effects of pollutants on specific areas of aquatic ecosystems by relying solely on one or several common patterns of organisms. Therefore, native species are more necessary to develop for environmental toxicological studies in vivo (Liang and Zha, 2016). Chinese rare minnows are Chinese native species and distributed mostly in the upstream region of the Yangtze River and in the Sichuan Province. This Cypriniformes species has been used extensively in recent years for aquatic toxicity testing (Chen et al., 2016; Yuan et al., 2013) and is considered an appropriate species for environmental toxicological studies due to its small size (30-80 mm total length), ease of culture, short life cycle, prolific egg production, and high fertilization and hatching rates.

In the present study, to investigate the underlying effects and mechanism of BaP-induced apoptosis on juvenile Chinese rare minnows at low concentrations, many toxicological endpoints, such as histology marking apoptosis of the liver, intestines, and gills, mRNA and protein expression changes, and enzyme activities of some key genes, were examined. We intend to investigate cellular apoptosis in different tissues of the rare minnow and thereby study the apoptotic pathway by which BaP exposure acts in vivo.

\section{Materials and methods}

All experimental protocols were approved by the Research Center for Eco-Environmental Sciences, Chinese Academy of Sciences, and the methods were carried out in accordance with the approved guidelines.

\subsection{Chemicals}

BaP (purity $>98 \%$ ) and acetone were purchased from AccuStandard Inc. (New Haven, CT, USA). A stock solution of BaP was prepared by dilution in acetone. Final content of acetone in all of the exposure media was less than $0.01 \%$.

\subsection{Fish care}

The rare minnow was kept in a flow-through system receiving charcoal-dechlorinated tap water (pH: 7.2-7.6; hardness: 44.0-61.0 $\mathrm{mg} \mathrm{CaCO}_{3}$ ) at a constant temperature of $25 \pm 1^{\circ} \mathrm{C}$, with a photoperiod of 16: $8 \mathrm{~h}$ (light: dark). All procedures for fish breeding were performed as described previously (Chen et al., 2016; Zha et al., 2007).

\subsection{BaP exposure}

Healthy juvenile rare minnows ( 3 months old) from the same pair of brood stock were used in this experiment. The average body weight and body length were $0.5 \pm 0.1 \mathrm{~g}$ and $37.0 \pm 2.1 \mathrm{~mm}$, respectively. Before exposure experiments were initiated, the fish were cultured for 2 weeks acclimation in 10 L glass tanks. Fish were exposed to BaP at different concentrations $(0,1,5,20$, and $80 \mu \mathrm{g} / \mathrm{L})$ with a solvent control. Each tank contained 15 fish, with 3 replicates were completed per treatment group. The exposure solutions were completely replaced once per day. Fish were fed twice a day with newly hatched brine shrimp. After 28 days exposure, the fish were removed from experimental tanks and anesthetized with MS222 (Sigma, USA). Livers, intestines and gills were immediately sacrificed in each group and fixed in Bouin's solution (SigmaAldrich, USA), and the rest of the rare minnow samples were flashfrozen in liquid nitrogen and stored at $-80^{\circ} \mathrm{C}$ for further analysis.

\subsection{Water concentrations of BaP}

BaP concentrations in the exposure solutions were analyzed by gas chromatography-mass spectrometry (GC-MSD) (Wang et al., 2007). Briefly, water samples were filtered using Millipore glass microfiber filters $(0.7 \mu \mathrm{m}, \mathrm{F} 142 \mathrm{~mm}$, Millipore, USA) and enriched by SPE with C18 coupled with HLB cartridges for $24 \mathrm{~h}$. The cartridges were eluted by DCM and concentrated under a stream of nitrogen. The samples were analyzed using an Agilent 6890 GC connected to an Agilent MSD 5975 mass selective detector (Agilent Technologies, USA). After $24 \mathrm{~h}$ of the test initiation, the concentrations (mean \pm standard deviation; \% analyzed/nominal) of $\mathrm{BaP}$ in the solutions were $0.8 \pm 0.1(80 \%), 3.8 \pm 0.9(76 \%), 14.5 \pm 3(72.5 \%)$, and $69.8 \pm 8.8(69.8 \%) \mu \mathrm{g} / \mathrm{L}$. Nominal BaP values are used in the following text.

\subsection{Histology}

After 30 days exposure, the liver, intestine, and gill of rare minnows were dissected and fixed in Bouin's solution at $4{ }^{\circ} \mathrm{C}$ overnight. Then the fixed tissues were dehydrated in gradient ethanol (50\%, 70\%, 75\%, 85\%, 90\%, 95\%, and 100\%), hyalinized in xylene, and embedded in paraffin wax at $55^{\circ} \mathrm{C}$. Sections were cut at $5 \mu \mathrm{m}$, stained with an H\&E Staining Kit purchased from Beyotime Institute of Biotechnology (Shanghai, China). An optical microscope (Zeiss, Germany) equipped with a digital camera, was used to observe the histologic lesions.

\subsection{TUNEL assay, Hoechst 33342 staining, and quantitation of apoptosis}

Tissues were immersed in $4 \%$ paraformaldehyde in a $0.1 \mathrm{~mol} / \mathrm{L}$ phosphate buffer. Fixation was carried out at $4{ }^{\circ} \mathrm{C}$ over night. Next, tissues were paraffin-embedded, cut into 5 - $\mu$ m-thick transverse sections and mounted on slides. Then, In Situ Cell Death Detection 
Kit (Roche, Switzerland) was used to detect the single- and doublestrand DNA breaks following the manufacturer's instructions (TUNEL assay). Finally, tissues were counterstained with Hoechst 33342 (Sigma, USA) for $5 \mathrm{~min}$ at room temperature and examined with a fluorescence microscope (OLYMPUS).

A quantitative method to assess TUNEL-positive cells was performed according to Soutschek et al. (Soutschek and Zupanc, 1996). The number of TUNEL-positive cells found in each section was corrected for split-cell errors through multiplication by a correction factor.

$N i=n i \times \frac{t}{t+d}$

where $N_{i}$ is the number of TUNEL positive cells present in section $i$, $n_{i}$ is the number of labeled cells actually counted in section $i, t$ is the section thickness, and $d$ is the mean diameter of the TUNEL-positive nuclear fragment in a cell. Ten fields at $400 \times$ magnification were counted per slide, the percentage of apoptotic cells in each field was calculated.

\section{7. $R T-q P C R$}

The expression levels of 7 genes (cyp1a1, p53, bcl-2, bax, caspase3 , caspase-9, and apaf-1) were measured by RT-qPCR. The amplification parameters were performed for $95^{\circ} \mathrm{C}$ for $10 \mathrm{~min}, 40$ cycles at $95^{\circ} \mathrm{C}$ for $10 \mathrm{~s}, 60^{\circ} \mathrm{C}$ for 10 s, and $72{ }^{\circ} \mathrm{C}$ for 10 s. Each sample was run in triplicate. The primers in this study are shown in Table S1 (Yuan et al., 2016). The PCR efficiencies ranged from $93.2 \%$ to $103.0 \%$ in the present study. RT-qPCR experiments were performed on a Mx3005P real-time quantitative polymerase chain reaction system (Stratagene, USA). Differences were calculated according to the $2^{-\Delta \Delta \mathrm{Ct}}$ method relative quantization method using $\beta$-actin as an internal control.

\subsection{Caspase 3, caspase 8, and caspase 9 activity assays}

The activity of caspase 3 , caspase 8 , and caspase 9 was determined using the caspase 3 , caspase 8 , and caspase 9 activity kit (Beyotime Institute of Biotechnology, China). The liver tissue sample lysates were prepared in the lysis buffer from the assay kits and were centrifuged at $12,000 \mathrm{rpm}$ for $15 \mathrm{~min}$ at $4{ }^{\circ} \mathrm{C}$. Then, the supernatants were collected and incubated at $37.8{ }^{\circ} \mathrm{C}$ for $2 \mathrm{~h}$. The caspase activities were measured in a 96-well plate at an absorbance of $405 \mathrm{~nm}$. The caspase activities were determined by a colorimetric assay based on the ability of caspase 3 , caspase 8 , and caspase 9 to change acetylAsp-Glu-Val-Aspp-nitroanilide (AcDEVD-pNA) and acetyl-Leu-Glu-His-Aspp-nitroanilide (Ac-LEHDpNA) into a yellow formazan product ( $p$-nitroaniline (pNA)). All results were expressed in $\mathrm{nmol} / \mathrm{h} /$ prot.

\subsection{Protein extraction and western blot analysis}

Protein extraction was performed using $50 \mathrm{mg}$ of frozen hepatic tissue per sample. The juvenile Chinese rare minnow livers were homogenized and sonicated intermittently in $500 \mu \mathrm{L}$ of ice-cold lysis buffer (7 M urea, $2 \mathrm{M}$ thiourea, $30 \mathrm{mM}$ Tris, $4 \% \mathrm{w} / \mathrm{v}$ CHAPS, $1 \% \mathrm{w} / \mathrm{v}$ DTT) containing a $10-\mu \mathrm{l}$ cocktail of protease inhibitors (M221, Amrecso, USA) on ice for $5 \mathrm{~min}$. Insoluble debris was removed by centrifugation at $12,000 \times \mathrm{g}$ for $20 \mathrm{~min}$ at $4{ }^{\circ} \mathrm{C}$, and the supernatant was collected. The supernatant was stored at $-80{ }^{\circ} \mathrm{C}$, and the total protein concentration was determined by a Bradford assay using a Protein Assay Kit II with a BSA standard (Bio-Rad).

Proteins from the livers of Chinese rare minnows were extracted and separated by SDS-PAGE and transferred to PVDF membranes
(Millipore). These blots were incubated for $1 \mathrm{~h}$ at room temperature in TBST containing 5\% skim milk. The anti-p53 polyclonal (\#9282, diluted 1:1000, Cell Signaling Technology), anti-Apaf-1 polyclonal (sc-8339, diluted 1:200, Santa Cruz), and anti-actin polyclonal (\#4967, diluted 1:1000, Cell Signaling Technology) primary antibodies were used. The blots were labeled with horseradish peroxidase-conjugated secondary antibody to rabbit IgG and visualized by ECL reagents (Pierce). Images were captured by ChemiDoc-It ${ }^{\mathbb{R}} 415$ Imager (UVP, USA) and analyzed by VisionWorksLS Image Acquisition and Analysis Software.

\subsection{Statistical analysis}

All data were analyzed with SPSS 16.0 software (SPSS, Chicago, IL, USA) and expressed as the mean \pm standard error of the mean (S.E.M.). Significant differences between different treatment groups were identified on the basis of $\mathrm{P}<0.05$ using one-way analysis of variance (ANOVA) and post hoc least significant difference (LSD) test.

\section{Results}

\subsection{Histopathology observation}

\subsubsection{Hepatic tissue}

The normal hepatic tissues showed closely packed polygonal hepatocytes in a regular array with well-defined nuclei (Fig. 1A). After 28 days of BaP exposure, hypertrophy of the hepatocytes from all treatment groups was observed (Fig. 1C). In addition, karyopyknosis and karyorrhexis of the heaptocytes from the 20 and $80 \mu \mathrm{g} / \mathrm{L}$ treatment groups were observed (Fig. 1B and C). These pathological changes in the liver cells following BaP treatments suggest that this compound seriously damages the liver tissues of Chinese rare minnow.

\subsubsection{Intestinal tissue}

Healthy intestinal tissue exhibits the structures of the intestinal wall and is composed of tunica mucosa, tunica submucosa, tunica muscularis, and tunica serosa (Fig. 1D). Intestinal mucosa displays many villi and a simple columnar epithelium, which are associated with goblet cells and intra-epithelial lymphocytes (Fig. 1D). The goblet cells exhibited a supranuclear region characterized by a swollen distal region containing a translucent cytoplasm and a basal region with associated nuclei. Intra-epithelial lymphocytes were small oval to round cells with deeply stained nuclei. After 28 days of BaP exposure, the abnormal intestine tissue from treatments showed that the number of goblet cells and physaliphores in the intestinal mucosa significantly increased (Fig. 1E). Moreover, ecclasis of the striated border of the intestinal mucosa from the 20 and $80 \mu \mathrm{g} / \mathrm{L}$ treatments was also observed (Fig. 1F). The pathological characteristics of the intestinal tissue suggested that BaP caused intestinal tissue toxicity in Chinese rare minnows.

\subsubsection{Gill tissue}

The structure of normal gill tissues exhibited well-shaped primary lamellae with cartilaginous tissue at the bottom and secondary lamellae. The gill's secondary lamellae are normally lined with squamous epithelial cells, which are one or two layers thick and contain a blood sinus spanned by pillar cells (Fig. 1G). After 28 days of exposure of $\mathrm{BaP}$, no significant histopathological changes were observed between the gills between the 1 and $5 \mu \mathrm{g} / \mathrm{L}$ treatments (data not shown). However, characteristic inflammatory and epithelial hyperplasia of the gill lamellae from the 20 and $80 \mu \mathrm{g} / \mathrm{L}$ treatments were observed (Fig. $1 \mathrm{H}$ ). Similarly, the histopathological results showed that $\mathrm{BaP}$ caused gill tissue lesions to occur at relatively higher concentrations. 

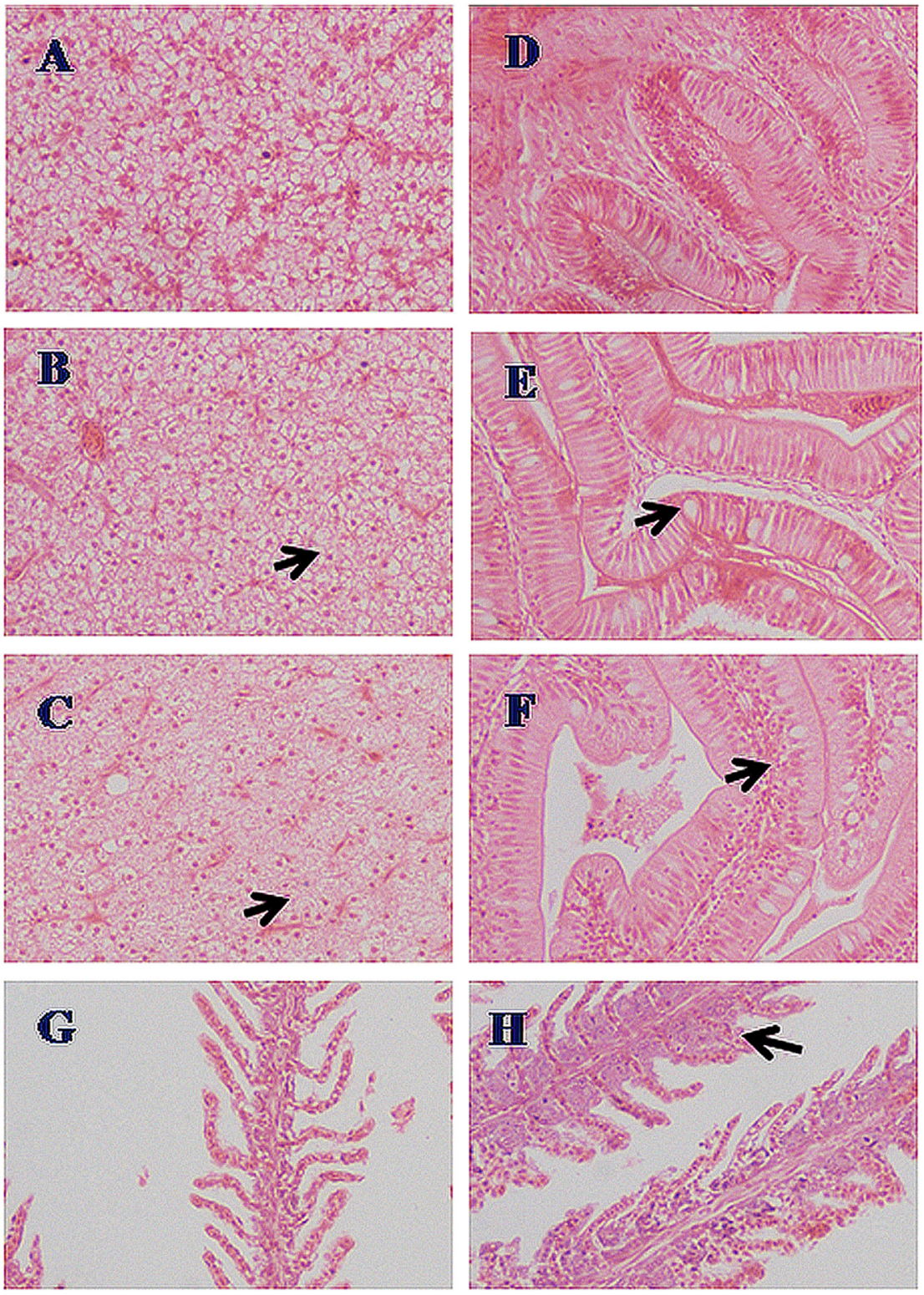

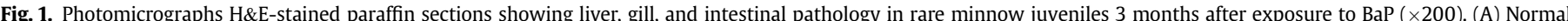

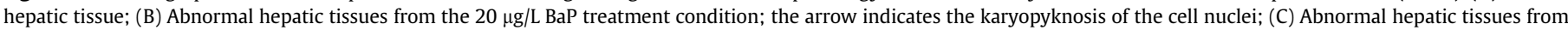

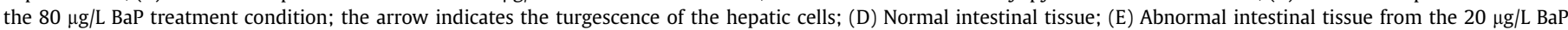

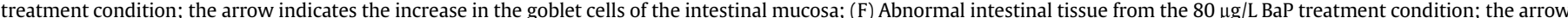

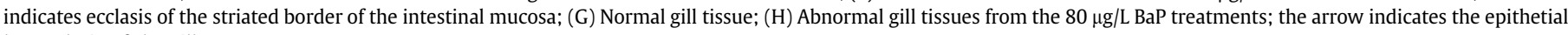
hyperplasia of the gills.

\subsection{BaP-induced hepatocyte apoptosis can be detected by TUNEL/ Hoechst 33342 double staining}

TUNEL-positive cells were identified by their red-stained nuclei. No TUNEL-positive cells were observed in the Hoechst 33342 staining cells (Fig. 2 and Fig. S1). After 28 days of BaP exposure, TUNEL-positive cells in the livers were clearly observed in all treatments (Fig. 2). These results showed that BaP significantly induced hepatocyte apoptosis in Chinese rare minnows. Similarly, these results are consistent with the levels of karyopyknosis and karyorrhexis of hepatocytes observed using the HE stain. The rates of apoptosis of hepatocytes increased with the BaP exposure concentrations. Chinese rare minnows subjected to higher treatments had significantly higher numbers of abnormal hepatocytes than the controls (Fig. 3). However, the rates of apoptosis in the gills and intestines from treatments did not show any significant differences with the controls (data not shown).

\subsection{Measurement of apoptosis-related gene expression levels by $R T-q P C R$}

The mRNA expression of apoptosis-related genes, including cyp1a1, p53, bax, bcl-2, caspase-3, caspase-9, and apaf-1 in the livers of Chinese rare minnows, were determined after 28 days of $\mathrm{BaP}$ exposure (Figs. 4 and 5). No significant differences were observed between the mRNA expression levels of the vehicle control and the water control in any of the genes assessed (data not shown). A strong induction of cyp $1 a 1$ following the 20 and $80 \mu \mathrm{g} / \mathrm{L}$ treatments 

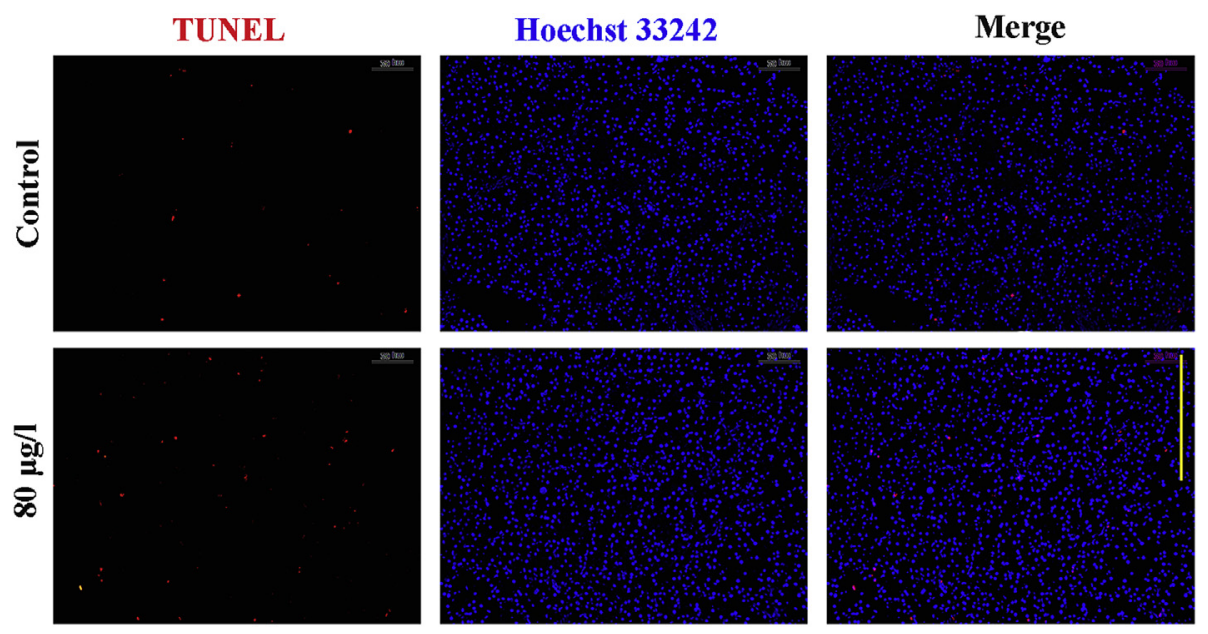

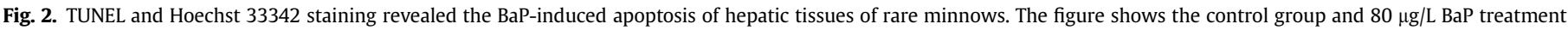
group. More details about the remaining treatment groups in Fig. S1. The induction of apoptosis was determined by fluorescence microscopy; scale bars = $100 \mu \mathrm{m}$.

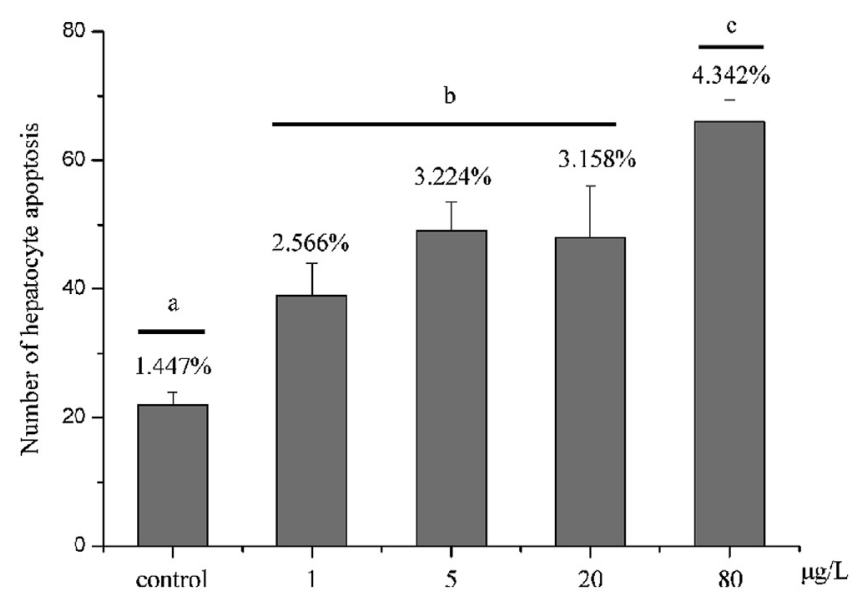

Fig. 3. Apoptotic index in the liver of Chinese rare minnows after exposure to benzo(a) pyrene for $28 \mathrm{~d}$. The data are expressed as the mean \pm S.E.M. of each treatment $(n=6)$. Significant differences between groups at $p<0.05$ (ANOVA) are indicated by different letters.

(8.30-fold and 46.33-fold, respectively) was observed (Fig. 4). The p53 mRNA level significantly increased with treatments higher than $5 \mu \mathrm{g} / \mathrm{L}$ (Fig. 4).

The mRNA level of the pro-apoptotic protein bax (the bcl2 associated $x$ protein) was significantly up-regulated with treatment concentrations higher than $5 \mu \mathrm{g} / \mathrm{L}$, with increases of 2.19 fold, 2.34 fold, and 4.02 fold (Fig. 4). However, the anti-apoptotic protein $b c l-2$ mRNA levels in livers with 5,20 and $80 \mu \mathrm{g} / \mathrm{L}$ BaP treatments increased by 1.97 fold, 1.52 fold, and 1.30 fold, respectively. In contrast, the mRNA levels of apaf-1 were significantly downregulated at all treatments, with decreases of $0.46,0.42,0.39$ and 0.47 fold with $1,5,20$, and $80 \mu \mathrm{g} / \mathrm{L} \mathrm{BaP}$ treatments, respectively (Fig. 5).

The mRNA expression levels of the two key genes (caspase-9 and caspase-3) of the caspase pathway were also determined. The mRNA level of caspase- 9 following $80 \mu \mathrm{g} / \mathrm{L}$ BaP treatments was significantly up-regulated compared to the control group (Fig. 5). However, the mRNA level of caspase-3 in the treatments was not significantly different with that of the controls (Fig. 5).

\subsection{Effects of BaP on the enzyme activity of caspase 3, caspase 8, and caspase 9}

To ascertain whether BaP-induced hepatocyte apoptosis occurred via a mitochondria-dependent pathway, we analyzed the effects of BaP on the enzyme activity levels of caspase 3, caspase 8 , and caspase 9. As shown in Fig. 6, the activity of caspase 3 in all treatment groups was induced in a dose-dependent manner after 28 days of exposure to BaP. Indeed, two of the high concentration groups (20.0 and $80.0 \mu \mathrm{g} / \mathrm{L} \mathrm{BaP}$ ) were significantly up-regulated (Fig. 6), which was consistent with the results observed in the TUNEL assay (Figs. 2 and 3).

The enzyme activity of caspase 9 and caspase 8 was also investigated, as these are the critical enzymes of the mitochondriadependent and mitochondria-independent pathways of apoptosis, respectively. The obtained results demonstrate that BaP significantly increased the enzyme activity levels of caspase 8 in all treatments, yet caspase 9 was found to have a dramatic up-regulation in the low concentration group only (20 and $80 \mu \mathrm{g} / \mathrm{L}$; Fig. 6).

\subsection{Apoptosis-related protein expression}

To further illustrate the apoptotic signaling after 28 days of $\mathrm{BaP}$ exposure, the protein expression levels of P53 and Apaf1 were investigated. As shown in Fig. 7, BaP induced a significant increase in P53 in the livers following the $5 \mu \mathrm{g} / \mathrm{L} \mathrm{BaP}$ treatments. Apaf1 was effectively inhibited by the 20 and $80 \mu \mathrm{g} / \mathrm{L}$ BaP treatments.

\section{Discussion}

The mechanism of cell apoptosis has been demonstrated for most polycyclic aromatic hydrocarbons (PAHs), including benzo(a) pyrene, and more information is needed concerning the role of low concentrations and chronic exposure, especially in vivo. The present investigation suggests that exposure to high concentrations of $\mathrm{BaP}$ for 28 days caused severe tissue toxicity and significantly induced cell apoptosis in the liver through the high responsiveness of apoptosis-related genes, proteins, and enzymes in the livers of juvenile Chinese rare minnows.

In the present study, severe pathological changes in the livers, gills, and intestines of juvenile Chinese rare minnows were observed following exposure to 20 and $80 \mu \mathrm{g} / \mathrm{L}$ of BaP (Fig. 1), and these results generally concur with the results of studies conducted 

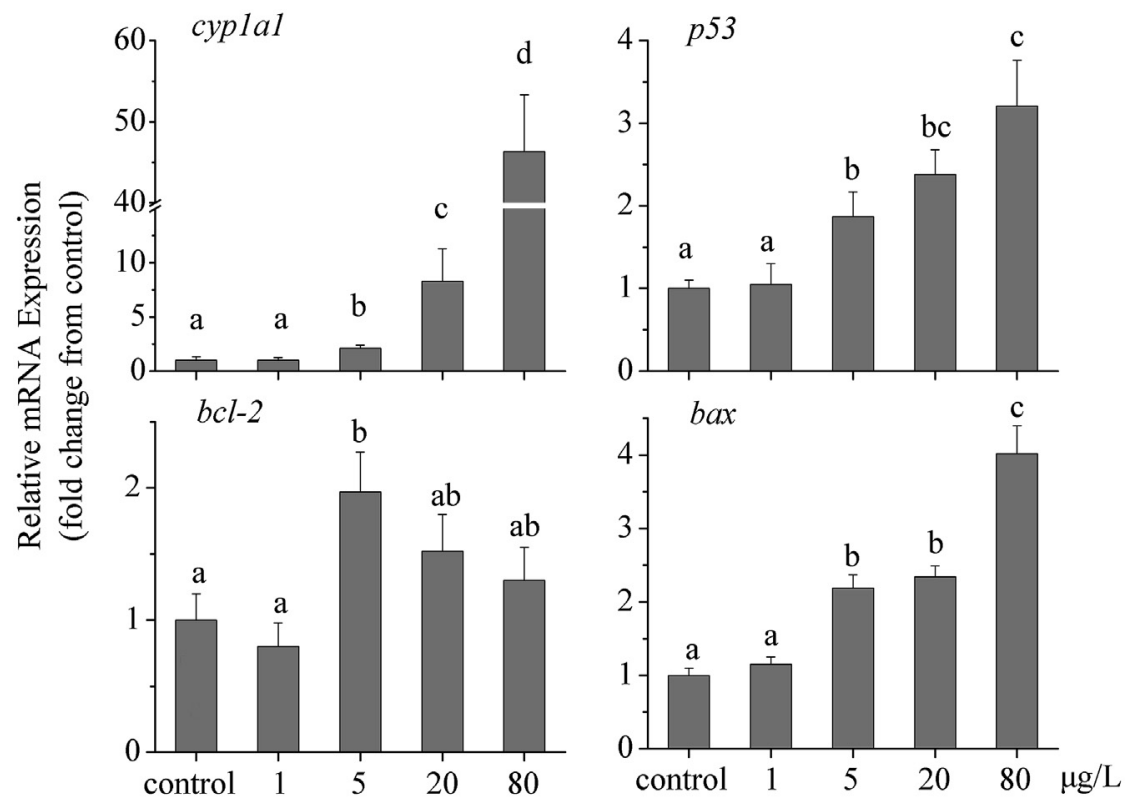

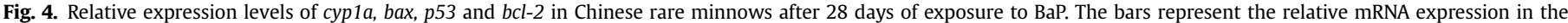

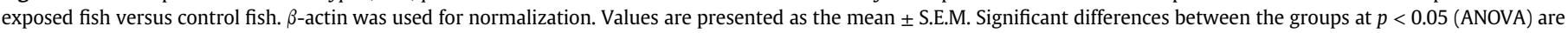
indicated by different letters.

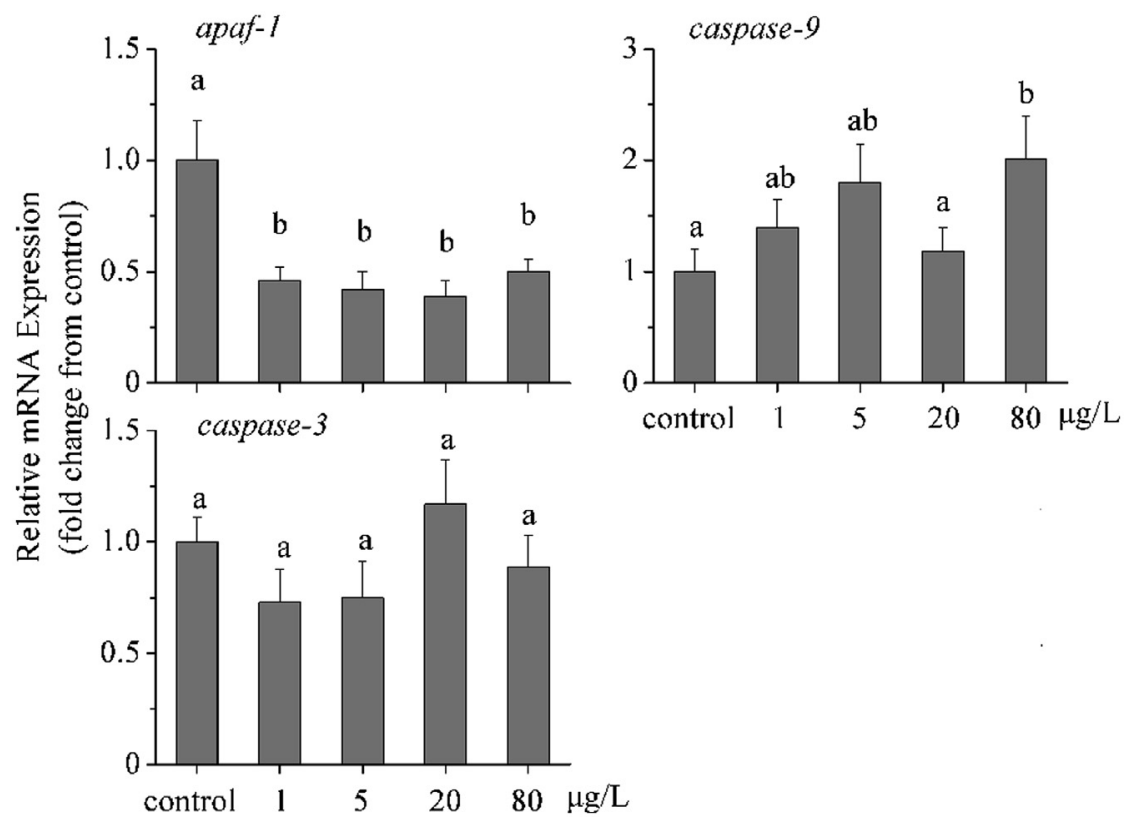

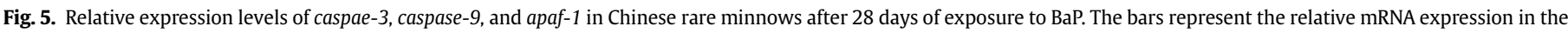

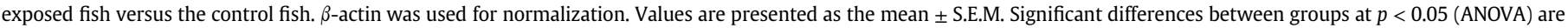
indicated by different letters.

previously using higher BaP concentrations (Wang et al., 2010; Wills et al., 2010). Pathological changes in the liver cells of Chinese rare minnows exposed to more than $5 \mu \mathrm{g} / \mathrm{L} \mathrm{BaP}$ were associated with cell turgescence, karyopyknosis and karyorrhexis (Fig. 1). These changes are identical to those previously observed in Arctic charr (Salvelinus alpinus) (Ribeiro et al., 2007) and rainbow trout (Oncorhynchus mykiss) (Möller et al., 2014). In this study, goblet cells of the intestinal mucosa from Chinese rare minnows exposed to more than $20 \mu \mathrm{g} / \mathrm{L}$ of BaP significantly increased. Similar pathological changes were also observed in Anabas testudineus exposed to almix (Samanta et al., 2016) and Cyprinus carpio exposed to effluent (Patil and Ghole, 2010). In addition, histopathological observations of the gills from Chinese rare minnows exposed to 20 and $80 \mu \mathrm{g} / \mathrm{L}$ of BaP revealed epithetial hyperplasia and amalgamation of secondary lamellae (Fig. 1). The changes were indicative of a diminished oxygen supply to the test fish, resulting in hypoxic respiratory responses (Abalaka et al., 2015; Das and Mukherjee, 2000). Therefore, our present findings provide evidence for hyperplasia as a protective mechanism against environmental irritants. 

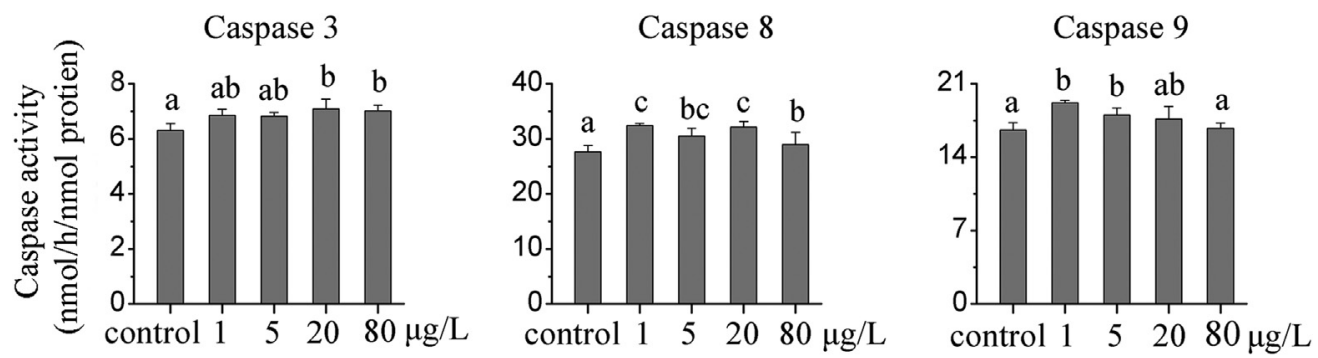

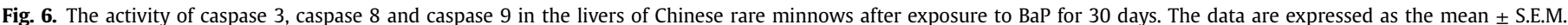
Significant differences between groups at $p<0.05$ (ANOVA) are indicated by different letters.
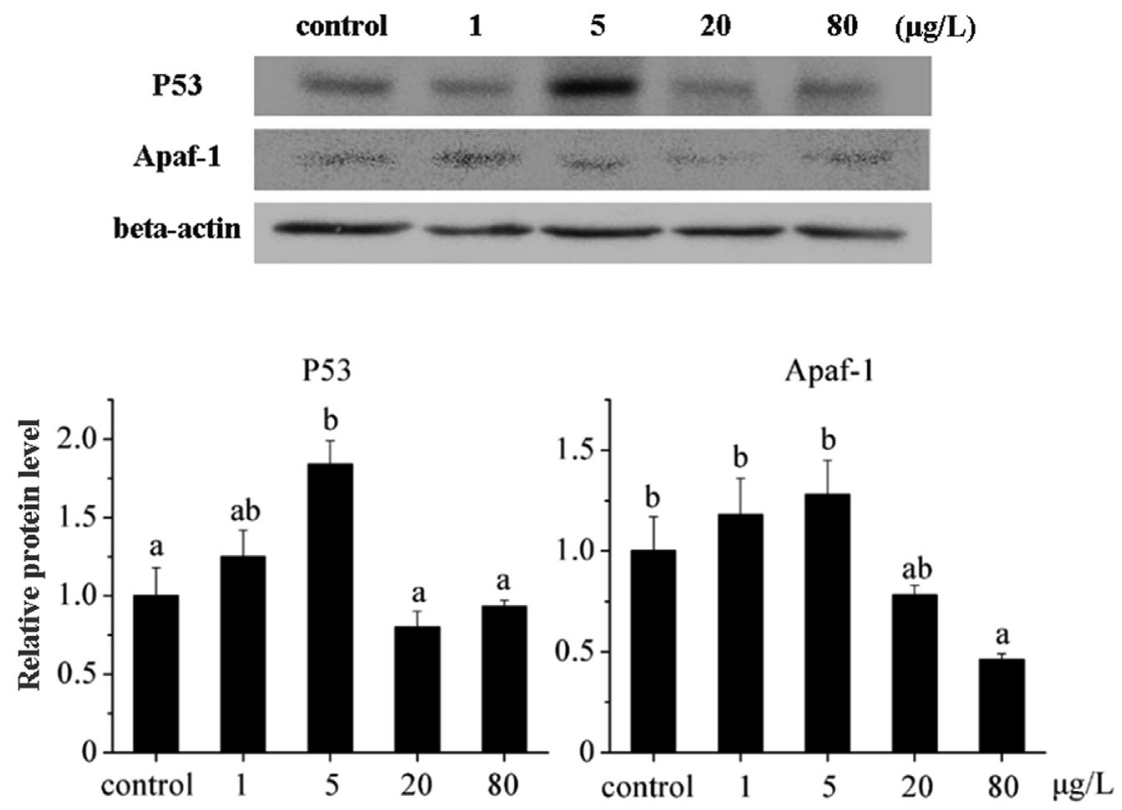

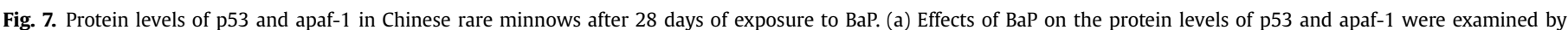

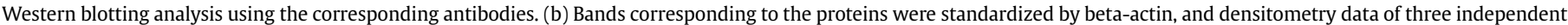
experiments are presented. The data are expressed as the mean \pm S.E.M.

Apoptosis is critical for normal development and occurs in many developmental stages in invertebrates and vertebrates. In previous studies, BaP induced apoptosis in RL95-2 human endometrial cancer cells (Kim et al., 2007) and lung cancer A549 cells (Lin et al., 2015). Similarly, a significant increase in hepatocyte apoptosis was observed in the present study with juvenile Chinese rare minnows exposed to BaP (Figs. 2 and 3), although apoptosis was not increased in the gills and intestines. These different results are likely due to differences in the functionality of these various tissues. Additionally, BaP induced hepatocyte apoptosis after sole (Solea senegalensis) were injected with approximately $5 \mathrm{nmol} \mathrm{BaP} \mathrm{g}^{-1}$ fish wet mass for $24 \mathrm{~h}$ incubation (Costa et al., 2010). Moreover, the lower percentage of apoptotic cells observed when compared to our results (Fig. 3) could be due to the shorter exposure time and lower concentrations (Costa et al., 2010). In addition, our present results show that $\mathrm{BaP}$ induced hepatocyte apoptosis in juvenile Chinese rare minnows in a dose dependent manner, and this result agrees with that of a previous study in vitro (Yoo et al., 2003). The present finding confirms different responses in different tissues of Chinese rare minnows exposed to BaP.

The biological impact of BaP depends on the functional activation of AHR, which induces the transcriptional activation of genes involved in drug metabolism (Huc et al., 2006; Souza et al., 2016).
Cyp1a1, the major drug-metabolizing enzyme, is one of the genes known to be activated, and it acts on BaP to produce the ultimate carcinogen BPDE-1 (Schmidt and Bradfield, 1996; Yuan et al., 2013). Our study has demonstrated that BaP strongly induces increased mRNA levels of cyp1a1 (Fig. 4). Similarly, cyp1a1 has been shown to be activated in RL95-2 human endometrial cancer cells exposed to $\mathrm{BaP}$ (Kim et al., 2007). It was observed that BaP metabolites cause DNA damage, which in turn initiates the transcriptional activation of many genes, such as p53 (Huc et al., 2006; Van Delft et al., 2012). In this study, the mRNA levels of $p 53$ were found to be significantly up-regulated, with an increase of 3.16 fold following exposure to the $80 \mu \mathrm{g} / \mathrm{L}$ BaP concentration (Fig. 4). Previous studies have indicated that the activation of the p53-related signaling pathway involves the induction of apoptosis in vitro (Lin et al., 2008). Protein levels of p53 were not observed to be significantly up-regulated following the 20 and $80 \mu \mathrm{g} / \mathrm{L} \mathrm{BaP}$ treatments (Fig. 7). Nevertheless, studies in human hepatoma HepG2 cells have shown that BaP exposure induced an obvious increase in phosphorylated P53 (Donauer et al., 2012; Park et al., 2006). In summary, our findings also reveal that the $p 53$-related signaling pathway is activated in vivo.

The $b c l 2$ proteins are known to regulate the intrinsic pathway; moreover, the ratios between the $b c l-2$ and bax proteins would change mitochondrial cytochrome $c$ release. Cytochrome $c$ associates 
with apaf-1 to form the apoptosome in the cytosol (Stenson-Cox et al., 2003). In the present study, the mRNA level of bcl-2 increased at higher concentrations of BaP, whereas the apaf-1 level decreased significantly with all concentrations (Figs. 4 and 5). Morever, the protein levels of Apaf- 1 were also down-regulated in the 20 and $80 \mu \mathrm{g} / \mathrm{L} \mathrm{BaP}$ treatment conditions (Fig. 7) and no obvious changes were observed in the enzyme activity of caspase 9, except in the lowest concentration group (Fig. 6). Therefore, these results suggested that it could be difficult to form the apoptosome in the cytosol and could induce caspase-independent apoptosis through the mitochondrial pathway. Additionally, there is no significant differences in the expression of caspase-3, whereas a significant increase of caspase-9 was observed only with $1 \mu \mathrm{g} / \mathrm{L} \mathrm{BaP}$ (Fig. 5). Our findings suggest that caspase 9 may not contribute to the activation of the mitochondria-dependent signaling pathway leading to hepatocyte apoptosis induced by 20 and $80 \mu \mathrm{g} / \mathrm{L}$ of BaP. Similarly, Holme et al. (2007) reported that BaP induces the caspase-independent apoptosis of hepatic F258 cells by blocking the intracellular translocation of bax and the cytochrome $c$ protein. In addition, previous studies have showed that B1-induced caspase-independent apoptosis in MCF-7 was mediated by the downregulation of $\mathrm{Bcl}-2$ (Liang et al., 2011). Nevertheless, a recent study showed that BaP-induced apoptosis of mouse livers occurs via the activation of the intrinsic caspase cascade and mitochondrial dysfunction (Qin et al., 2015). Thus, it should be noted that the BaP-induced caspase independent apoptosis in vivo is very different in vitro. Accordingly, to further confirm the apoptosis pathway of $\mathrm{BaP}$ in vivo, the caspase 8 activity assay in our study was determined, and we found that it was significantly activated by exposure to BaP in all treatments (Fig. 6). This indicates that both intrinsic and extrinsic caspase-independent apoptosis pathways are activated by $\mathrm{BaP}$ in the low concentration groups. However, the intrinsic caspase-independent apoptosis pathway was weakened by the decrease of the Apaf- 1 protein expression levels in high concentration groups. Briefly, the pathways of hepatocyte apoptosis induced by different concentrations of BaP were different. Despite this, responses to apoptosis-related genes would be useful in order to discover the apoptosis pathways that occur in response to environmental contaminants in vivo.

\section{Conclusion}

In summary, juvenile Chinese rare minnows exposed to BaP for 28 days show significant histopathological changes, induced apoptosis, and changes in the expression of apoptosis-related genes. Moreover, BaP significantly induced apoptosis in the liver but not in the gill or intestine. Our findings further elucidated the BaP-induced caspase dependent apoptosis pathway and found differences in the intrinsic caspase dependent pathways mediated by different concentrations of BaP. Despite this, more studies are warranted to study the gene expression and protein level changes that occur in cell apoptosis pathways in vivo.

\section{Conflict of interest}

The authors report no declarations of interest.

\section{Acknowledgements}

This work was supported by Program of the National Natural Science Foundation of China (21677165), the Major International Joint Research Project of the National Natural Science Foundation of China (51420105012), and the Water Pollution Control and Treatment of the National Science and Technology Major Project (2014zX-07204-008-003)

\section{Appendix A. Supplementary data}

Supplementary data related to this article can be found at http:// dx.doi.org/10.1016/j.envpol.2017.08.005.

\section{References}

Aachoui, Y., Sagulenko, V., Miao, E.A., Stacey, K.J., 2013. Inflammasome-mediated pyroptotic and apoptotic cell death, and defense against infection. Curr. Opin. Microbiol. 16, 319-326. http://dx.doi.org/10.1016/j.mib.2013.04.004.

Abalaka, S.E., Fatihu, M.Y., Ibrahim, N.D.G., Ambali, S.F., 2015. Gills and skin histopathological evaluation in African sharptooth catfish, Clarias gariepinus exposed to ethanol extract of Adenium obesum stem bark. Egypt. J. Aquat. Res. 41, 119-127. http://dx.doi.org/10.1016/j.ejar.2015.01.005.

Chakraborty, D., Bishayee, K., Ghosh, S., Biswas, R., Kumar Mandal, S., Rahman Khuda-Bukhsh, A., 2012. [6]-Gingerol induces caspase 3 dependent apoptosis and autophagy in cancer cells: drug-DNA interaction and expression of certain signal genes in HeLa cells. Eur. J. Pharmacol. 694, 20-29. http://dx.doi.org/ 10.1016/j.ejphar.2012.08.001.

Chen, R., Liu, C., Yuan, L., Zha, J., Wang, Z., 2016. 2, 4-Dichloro-6-nitrophenol, a photonitration product of 2, 4-dichlorophenol, caused anti-androgenic potency in Chinese rare minnows (Gobiocypris rarus). Environ. Pollut. 216, 591-598. http://dx.doi.org/10.1016/j.envpol.2016.06.016.

Chung, J.Y., Kim, J.Y., Kim, W.R., Lee, S.G., Kim, Y.J., Park, J.E., Hong, Y.P., Chun, Y.J., Park, Y.C., Oh, S., Yoo, K.S., Yoo, Y.H., Kim, J.M., 2007. Abundance of aryl hydrocarbon receptor potentiates benzo[a]pyrene-induced apoptosis in Hepa1c1c7 cells via CYP1A1 activation. Toxicology 235, 62-72. http://dx.doi.org/ 10.1016/j.tox.2007.03.013.

Costa, P.M., Chicano-Gálvez, E., López Barea, J., Delvalls, T.A., Costa, M.H., 2010. Alterations to proteome and tissue recovery responses in fish liver caused by a short-term combination treatment with cadmium and benzo[a]pyrene. Environ. Pollut. 158, 3338-3346. http://dx.doi.org/10.1016/j.envpol.2010.07.030.

Das, B.K., Mukherjee, S.C., 2000. A histopathological study of carp (Labeo rohita) exposed to hexachlorocyclohexane. Vet. Arh. 70, 169-180.

de Oliveira, M.R., 2016. Fluoxetine and the mitochondria: a review of the toxicological aspects. Toxicol. Lett. 258, 185-191. http://dx.doi.org/10.1016/ j.toxlet.2016.07.001.

Donauer, J., Schreck, I., Liebel, U., Weiss, C., 2012. Role and interaction of p53, BAX and the stress-activated protein kinases p38 and JNK in benzo(a)pyrenediolepoxide induced apoptosis in human colon carcinoma cells. Arch. Toxicol 86, 329-337. http://dx.doi.org/10.1007/s00204-011-0757-3.

Hirano, M., Tanaka, S., Asami, O., 2013. Classification of polycyclic aromatic hydrocarbons based on mutagenicity in lung tissue through DNA microarray. Environ. Toxicol. 28, 652-659. http://dx.doi.org/10.1002/tox.20761.

Hockley, S.L., Arlt, V.M., Jahnke, G., Hartwig, A., Giddings, I., Phillips, D.H., 2008 Identification through microarray gene expression analysis of cellular responses to benzo(a)pyrene and its diol-epoxide that are dependent or independent of p53. Carcinogenesis 29, 202-210. http://dx.doi.org/10.1093/carcin/bgm227.

Holme, J.A., Gorria, M., Arlt, V.M., Øvrebø, S., Solhaug, A., Tekpli, X., Landvik, N.E. Huc, L., Fardel, O., Lagadic-Gossmann, D., 2007. Different mechanisms involved in apoptosis following exposure to benzo[a]pyrene in F258 and Hepa1c1c7 cells. Chem. Biol. Interact. 167, 41-55. http://dx.doi.org/10.1016/ j.cbi.2007.01.008.

Huang, L., Zuo, Z., Zhang, Y., Wang, C., 2015. Toxicogenomic analysis in the combined effect of tributyltin and benzo[a]pyrene on the development of zebrafish embryos. Aquat. Toxicol. 158, 157-164. http://dx.doi.org/10.1016/ j.aquatox.2014.10.024.

Huang, M.C., Chen, F.Y., Chou, M.T., Su, J.G.J., 2012. Fluoranthene enhances p53 expression and decreases mutagenesis induced by benzo[a]pyrene. Toxicol. Lett. 208, 214-224. http://dx.doi.org/10.1016/j.toxlet.2011.11.011.

Huc, L., Rissel, M., Solhaug, A., Tekpli, X., Gorria, M., Torriglia, A., Holme, J.A., Dimanche-Boitrel, M.T., Lagadic-Gossmann, D., 2006. Multiple apoptotic pathways induced by p53-dependent acidification in benzo[a]pyrene-exposed hepatic F258 cells. J. Cell. Physiol. 208, 527-537. http://dx.doi.org/10.1002/ jcp.20686.

Kikuchi, H. Shibazaki, M., Ahmed, S., Baba, T, 2001. Method for evaluation of immunotoxicity of dioxin compounds using human T-lymphoblastic cell line, LMAT. Chemosphere 43, 815-818. http://dx.doi.org/10.1016/S0045-6535(00) 00438-0.

Kim, J.Y., Chung, J.Y., Park, J.E., Lee, S.G., Kim, Y.-J., Cha, M.-S., Han, M.S., Lee, H.-J., Yoo, Y.H., Kim, J.-M., 2007. Benzo[a]pyrene induces apoptosis in RL95-2 human endometrial cancer cells by cytochrome P450 1A1 activation. Endocrinology 148, 5112-5122. http://dx.doi.org/10.1210/en.2007-0096.

Kim, K.H., Jahan, S.A., Kabir, E., Brown, R.J.C., 2013. A review of airborne polycyclic aromatic hydrocarbons (PAHs) and their human health effects. Environ. Int. 60, 71-80. http://dx.doi.org/10.1016/j.envint.2013.07.019.

Kobayashi, D., Ahmed, S., Ishida, M., Kasai, S., Kikuchi, H., 2009. Calcium/calmodulin signaling elicits release of cytochrome c during 2,3,7,8-tetrachlorodibenzo-pdioxin-induced apoptosis in the human lymphoblastic T-cell line, L-MAT. Toxicology 258, 25-32. http://dx.doi.org/10.1016/j.tox.2009.01.002.

Krais, A.M., Speksnijder, E.N., Melis, J.P.M., Indra, R., Moserova, M., Godschalk, R.W., van Schooten, F.J., Seidel, A., Kopka, K., Schmeiser, H.H., Stiborova, M. Phillips, D.H., Luijten, M., Arlt, V.M., 2016. The impact of p53 on DNA damage 
and metabolic activation of the environmental carcinogen benzo[a]pyrene: effects in $\operatorname{Trp} 53(+/+), \operatorname{Trp} 53(+/-)$ and $\operatorname{Trp53}(-/-)$ mice. Arch. Toxicol. 90 839-851. http://dx.doi.org/10.1007/s00204-015-1531-8.

Ladwani, K.D., Ladwani, K.D., Ramteke, D.S., 2013. Assessment of poly aromatic hydrocarbon (PAH) dispersion in the near shore environment of Mumbai, India after a large scale oil spill. Bull. Environ. Contam. Toxicol. 90, 515-520. http:// dx.doi.org/10.1007/s00128-012-0955-6.

Liang, X., Xu, K., Xu, Y., Liu, J., Qian, X., 2011. B1-induced caspase-independent apoptosis in MCF-7 cells is mediated by down-regulation of Bcl-2 via p53 binding to P2 promoter TATA box. Toxicol. Appl. Pharmacol. 256, 52-61. http:/ dx.doi.org/10.1016/j.taap.2011.07.010.

Liang, X., Zha, J., 2016. Toxicogenomic applications of Chinese rare minnow (Gobiocypris rarus) in aquatic toxicology. Comp. Biochem. Physiol. Part D. Genomics Proteomics 19, 174-180. http://dx.doi.org/10.1016/j.cbd.2016.06.007.

Lin, C.M., Kao, W.C., Yeh, C.A., Chen, H.J., Lin, S.Z., Hsieh, H.-H., Sun, W.S., Chang, C.H., Hung, H.S., 2015. Hyaluronic acid-fabricated nanogold delivery of the inhibitor of apoptosis protein-2 siRNAs inhibits benzo[a]pyrene-induced oncogenic properties of lung cancer A549 cells. Nanotechnology 26, 105101. http:// dx.doi.org/10.1088/0957-4484/26/10/105101.

Lin, T., Mak, N.K., Yang, M.S., 2008. MAPK regulate p53-dependent cell death induced by benzo[a]pyrene: involvement of p53 phosphorylation and acetylation. Toxicology 247, 145-153. http://dx.doi.org/10.1016/j.tox.2008.02.017.

Marino, G., Niso-Santano, M., Baehrecke, E.H., Kroemer, G., 2014. Self-consumption: the interplay of autophagy and apoptosis. Nat. Rev. Mol. Cell Biol. 15, 81-94. http://dx.doi.org/10.1038/nrm3735.

Möller, A.M., Korytář, T., Köllner, B., Schmidt-Posthaus, H., Segner, H., 2014. The teleostean liver as an immunological organ: intrahepatic immune cells (IHICs) in healthy and benzo[a]pyrene challenged rainbow trout (Oncorhynchus mykiss). Dev. Comp. Immunol. 46, 518-529. http://dx.doi.org/10.1016 j.dci.2014.03.020.

Park, S.Y., Lee, S.M., Ye, S.K., Yoon, S.H., Chung, M.H., Choi, J., 2006. Benzo[a]pyreneinduced DNA damage and p53 modulation in human hepatoma HepG2 cells for the identification of potential biomarkers for PAH monitoring and risk assessment. Toxicol. Lett. 167, 27-33. http://dx.doi.org/10.1016/j.toxlet.2006.08.011.

Patil, V., Ghole, V., 2010. Comparative toxicological studies of distillery effluent treatments such as UASB reactor followed by an oxidizer unit using Cyprinus carpio fish. Environ. Technol. 31, 185-191. http://dx.doi.org/10.1080/ 09593330903426679.

Qin, G., Wu, M., Sang, N., 2015. Sulfur dioxide and benzo(a)pyrene trigger apoptotic and anti-apoptotic signals at different post-exposure times in mouse liver Chemosphere 139, 318-325. http://dx.doi.org/10.1016 j.chemosphere.2015.06.052.

Ribeiro, C., Padros, J., Domingos, F., Akaishi, F., Pelletier, E., 2007. Histopathological evidence of antagonistic effects of tributyltin on benzo[a]pyrene toxicity in the Arctic charr (Salvelinus alpinus). Sci. Total Environ. 372, 549-553. http:/ dx.doi.org/10.1016/j.scitotenv.2006.10.005.

Samanta, P., Pal, S., Mukherjee, A.K., Kole, D., Ghosh, A.R., 2016. Histopathologica study in stomach and intestine of Anabas testudineus (Bloch, 1792 ) under almix exposure. Fish. Aquac. J. 7 http://dx.doi.org/10.4172/2150-3508.1000177.

Schmidt, J.V., Bradfield, C.A., 1996. Ah receptor signaling pathways. Annu. Rev. Cell Dev. Biol. 12, 55-89. http://dx.doi.org/10.1146/annurev.cellbio.12.1.55.

Soutschek, J., Zupanc, G.K.H., 1996. Apoptosis in the cerebellum of adult teleost fish Apteronotus leptorhynchus. Dev. Brain Res. 97, 279-286. http://dx.doi.org/ 10.1016/S0165-3806(96)00145-9.

Souza, T., Jennen, D., van Delft, J., van Herwijnen, M., Kyrtoupolos, S., Kleinjans, J.
2016. New insights into BaP-induced toxicity: role of major metabolites in transcriptomics and contribution to hepatocarcinogenesis. Arch. Toxicol. 90, 1449-1458. http://dx.doi.org/10.1007/s00204-015-1572-z.

Stenson-Cox, C., FitzGerald, U., Samali, A., 2003. In the cut and thrust of apoptosis, serine proteases come of age. Biochem. Pharmacol. 66, 1469-1474. http:/ dx.doi.org/10.1016/S0006-2952(03)00499-4.

Sun, J.H., Wang, G.L., Chai, Y., Zhang, G., Li, J., Feng, J., 2009. Distribution of polycyclic aromatic hydrocarbons (PAHs) in Henan Reach of the Yellow River, Middle China. Ecotoxicol. Environ. Saf. 72, 1614-1624. http://dx.doi.org/10.1016/ j.ecoenv.2008.05.010.

Van Delft, J., Gaj, S., Lienhard, M., Albrecht, M.W., Kirpiy, A., Brauers, K., Claessen, S., Lizarraga, D., Lehrach, H., Herwig, R., Kleinjans, J., 2012. Rna-seq provides new insights in the transcriptome responses induced by the carcinogen benzo[a] pyrene. Toxicol. Sci. 130, 427-439. http://dx.doi.org/10.1093/toxsci/kfs250.

Verbrugge, I., Johnstone, R.W., Smyth, M.J., 2010. SnapShot: extrinsic apoptosis pathways. Cell 143, 1192. http://dx.doi.org/10.1016/j.cell.2010.12.004 e2.

Wang, L., Camus, A.C., Dong, W., Thornton, C., Willett, K.L., 2010. Expression of CYP1C1 and CYP1A in Fundulus heteroclitus during PAH-induced carcinogenesis. Aquat. Toxicol. 99, 439-447. http://dx.doi.org/10.1016/ j.aquatox.2010.06.002.

Wang, Z., Li, J., Hesham, A.E.L., He, S., Zhang, Y., Wang, Z., Yang, M., 2007. Co-variations of bacterial composition and catabolic genes related to $\mathrm{PAH}$ degradation in a produced water treatment system consisting of successive anoxic and aerobic units. Sci. Total Environ. 373, 356-362. http://dx.doi.org/10.1016/ j.scitotenv.2006.11.020

Wills, L.P., Jung, D., Koehrn, K., Zhu, S., Willett, K.L., Hinton, D.E., di Giulio, R.T., 2010. Comparative chronic liver toxicity of benzo[a]pyrene in two populations of the atlantic killifish (Fundulus heteroclitus) with different exposure histories. Environ. Health Perspect. 118, 1376-1381. http://dx.doi.org/10.1289/ehp.0901799.

Wohak, L.E., Krais, A.M., Kucab, J.E., Stertmann, J., Øvrebø, S., Seidel, A., Phillips, D.H. Arlt, V.M., 2016. Carcinogenic polycyclic aromatic hydrocarbons induce CYP1A1 in human cells via a p53-dependent mechanism. Arch. Toxicol. 90, 291-304. http://dx.doi.org/10.1007/s00204-014-1409-1.

Wu, C.C., Bratton, S.B., 2013. Regulation of the intrinsic apoptosis pathway by reactive oxygen species. Antioxid. Redox Signal 19, 546-558. http://dx.doi.org/ 10.1089/ars.2012.4905.

Yoo, J., Ghiassi, M., Jirmanova, L., Balliet, A.G., Hoffman, B., Fornace, A.J., Liebermann, D.A., Böttinger, E.P., Roberts, A.B., 2003. Transforming growth factor- $\beta$-induced apoptosis is mediated by smad-dependent expression of GADD45b through p38 activation. J. Biol. Chem. 278, 43001-43007. http:// dx.doi.org/10.1074/jbc.M307869200.

Yuan, L., Lv, B., Zha, J., Wang, Z., 2016. Benzo[a]pyrene induced p53-mediated cell cycle arrest, DNA repair, and apoptosis pathways in Chinese rare minnow ( Gobiocypris rarus). Environ. Toxicol. 24, 296-303. http://dx.doi.org/10.1002/ tox.22298.

Yuan, L., Lv, B., Zha, J., Wang, Z., Wang, W., Li, W., Zhu, L., 2013. New cytochrome P450 1B1, 1C1, 2Aa, 2Y3, and 2K genes from Chinese rare minnow (Gobiocypris rarus): molecular characterization, basal expression and response of rare minnow CYP1s and CYP2s mRNA exposed to the AHR agonist benzo[a]pyrene. Chemosphere 93, 209-216. http://dx.doi.org/10.1016/ j.chemosphere.2013.04.064.

Zha, J., Wang, Z., Wang, N., Ingersoll, C., 2007. Histological alternation and vitellogenin induction in adult rare minnow (Gobiocypris rarus) after exposure to ethynylestradiol and nonylphenol. Chemosphere 66, 488-495. http:// dx.doi.org/10.1016/j.chemosphere.2006.05.071. 